\section{INTERNATIONAL JOURNAL OF \\ ECO-CULTURAL TOURISM, HOSPITALITY PLANNING \\ AND DEVELOPMENT}

VOLUME 4, ISSUE 2, 2021, $1-8$.

\title{
The Variations in writing the name of Djedu Nome (Busiris) in Coffin Texts
}

\author{
Mahmoud Hassan Ali ${ }^{1}$
}

Prof. Dr. Sherif El Sabban ${ }^{2}$

1PhD candidate, Department of Tourist Guidance faculty of tourism and hotels Minia University

2 Professor of Egyptology Department of Tourist faculty of tourism and hotels Guidance Minia University

\begin{abstract}
The Coffin Texts are considered one of the most important religious sources in ancient Egypt. And it's containing of a large number of names of deities, cities, regions and holy places. The number of times that deities or cities were mentioned, perhaps the reason for this is the size of the importance of those cities and these deities. the most sacred and important cities are the ones that have mentioned more times in the coffin texts, especially those that had an important role in the afterlife. The way and forms of writing the names of the se cities varied for some reason, and this gives another importance to these cities in addition to their religious significance. In this study I will investigate the city of Djedu in terms of the written differences and the forms of signs and the reasons for their differences in each incantation in the Egyptian Coffin Texts, and this will be through reviewing and reading the texts and making an analytical study of the written forms of the city and the cases in which they were written.

This study will focus on the different forms and symbols which has been used for the writing the name of Djedu, and the main sources for these study will be the religious texts, especially the Coffin texts, and try to understand why the major differences of the writings of the name Djedu, also try to make a list and Index for those variations in the writing of the name of Djedu.

Keywords

Djedu, Coffin Texts, Spell
\end{abstract}

\section{Introduction}

The capital of the ninth Lower Egyptian Nome was Abusir Bana (An. Eg. Djedu, Gk. Busiris). The site of Djedu may have a very long history, although lack of Archaeological research at this large tell site hampers our knowledge of any Predynastic origins; Late Period to Roman remains cover the surface of the site1.

It is uncertain whether Andjety (a river and vegetation god) was the patron god of Djedu, but the region was originally known as Andjety's Nome2. In the Pyramid Texts, the king ${ }^{\text {ee }}$ s power is associated with this god3 and King Sneferu is shown wearing the double plumed crown of Andjety on a relief now in the Cairo Museum4. Andjety - many of whose attributes were later assimilated By Osiris5- may have had a temple at Djedu during the Third Dynasty. The earliest evidence for

\footnotetext{
1 Tassie, G. J., Prehistoric Egypt, 96.

${ }^{2}$ Wilkinson, the Complete Gods and Goddesses of Ancient Egypt, 97, 98.

3 Allen, J. P.,2005 The Ancient Egyptian Pyramid Texts,182.

${ }^{4}$ Saleh, M., Sourouzian, H., Official Catalogue: The Egyptian Museum Cairo, No.24.

${ }^{5}$ Griffiths, J. G., The Origins of Osiris and his cult, 136-138.
} 
INTERNATIONAL JOURNAL OF

ECO-CULTURAL TOURISM, HOSPITALITY PLANNING

AND DEVELOPMENT

VOLUME 4, ISSUE 1, 2021, 149 - 157.

www.egyptfuture.org/ojs/

Andjety ${ }^{\text {ee }}$ Nome is an inscription from a Saqqara mastaba dating to the late Third Dynasty of the official Pehernefer, who describes Himself amongst other titles as hiti-c [provincial governor] of Andjety"s Nome"6. The Palermo Stone, in the section of Sahure"s annals, mentions donations being made to several gods, including to Mesen and Sem, whose temples it states were in Andjety"s Nome7 . Could the individual(s) buried at Quesna have been a priest in one of these temples and where were they located?

\section{The writings of Djedu (Busiris) name in Coffin Texts:}

The most common way on writing the name of Djedu as follow

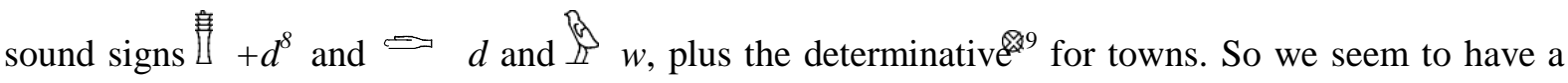
word with the sound $+d+d+w$, while the determinative tells that they spell the name of a Nome.

When a second sound sign like $\overbrace{}^{10}$ is accompanied by a first sound sign like and the latter matches one of the sounds the former, then the first sound sign reinforces the reading of the second sound sign. It does not give new information, so we do not read it as separate sound.

In the name of Djedu above we have $\frac{\text { 至 }}{4} d$ followed by $\Longrightarrow d$. The sign $\Rightarrow$ matching of the sounds of

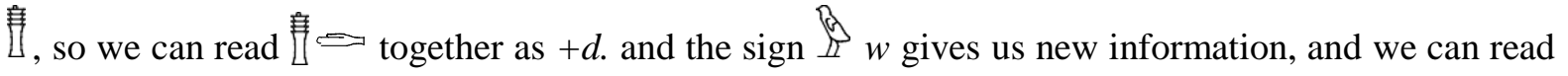
$+d w$, This name of Nome, which we know in English as Djedu.

The determinatives will normally come at the end of words-and usually they do, while, sometimes they donet have to. When we look at $+d w$ we have the signs $+d$ and $\$ w$, which are tall narrow signs; between them we have $\Longrightarrow d$, which is low broad sign; while the determinative is low narrow sign. In the expected sequence

6 Maspero, G., Un Manuel de Hiérarchie gyptienne et le culte une et les Bestiaux dans les Tableaux des tombeaux de L'ancien Empire, 246-272.

${ }^{7}$ Sethe, K. H., Urkunden des Alten Reichs, 244.

${ }^{8}$ Some Egyptologists maintained that the djed-pillar isn"t exclusively an aniconic statue and emblem of Osiris"e resurrection or even a symbol of the god"s backbone. It also depicts four superimposed capitals or four pillars one behind another according to Egyptian ideas of perspective (Moret 1926, 93). As a result it has been suggested that the sacred pillar of Osiris represents equally the four pillars of heaven (Kristensen 1925, 104; Van Dijk 1993, 171, n. 81; Clark 1959, 236 and PT 389-390a). Its cosmic role derives from its meaning (djed=stability) and properties (it is often depicted to support heaven"s ocean, Mayassis 1966, 649 ff, fig. 592; Demel 1944; Leclant 1946, 174-5). For more commentaries on djed"s symbolism, see Gordon-Schwabe 2004, 114 ff.; Mayassis 1966, vol. 1, 648 ff.

${ }^{9}$ The phonetic is (niwt) means, town site-city-region. The ancient Egyptian (hieroglyph) Town site-city-region is Gardiner sin listed number $\mathrm{Q} 49$ for the intersection of a town's streets. In some Egyptian hieroglyphic books it's called a city plan.

Efthymios Lazongas, Gates and Pillars of Heaven the Architectural Structure of Cosmos in Greek, Egyptian and Near Eastern Tradition and Art, 275.

${ }^{11} \mathrm{~Wb}$ V, 630.7; LGG VII, 685 
awkward arrangement, which leaves spaces in the inscription. So here the sculptor has moved over the back of 1 to fill up the space.

In

$31,32,34,45,47,50,60,132,144,146,155,156,182,197,206,215,228,268,292,303,312,314,315,339,355,3$

$70,375,434,456,629,660,797,918,1087$, the writing of the Nome of Djedu as available for an inscription was very restricted, an even briefer writing of the same word would be $\Rightarrow 13$. Scribes could vary the make-up of words, abbreviating them or spelling them out more fully, in order to make the most pleasing and varied arrangement within an inscription, whether horizontally or vertically, but here in this common case the artist spelling and writing them out more fully.

And in CT Spells 26, 37, 335 ${ }^{14}, 338$ the writing of the Nome of Djedu as ${ }^{15}$, so the name here in those three spells abbreviated, without letter $\Longrightarrow$, and we still can read it $+d w$, because $\Longrightarrow$ an extra sign known as phonetic complement.

In CT Spells 312, 622, 772, Djedu written as and determinative it will be enough to read it $+d w$ because the Djed pillar is two consonants (Two sounds) $D+d$, but in this example he repeated the sign letter $\leftrightharpoons$ two times, maybe in this case, referring to the scribe way of speaking.

This may confirm the possibility that the coffin texts were written by more than one scribe, for each single coffin ${ }^{16}$.

In CT Spell 313, Djedu Nome has been written as $\Rightarrow$, the two djed pillars ${ }^{18}$ here has two sound for the same latter djed, $D$ so the second phonogram of djed pillar doesn't add any more meaning, just the way of scribe in writing ${ }^{19}$.

The first Djed pillar probably belongs to the god of Djedu, Andjety and then Osiris, but the second Djed pillar referring to the name of the city Djedu (Busiris), the reason of it is the linguistic rules used in the ancient Egyptian language.

\footnotetext{
12 James P.Allen, Middle Egyptian, 472.

${ }^{13}$ Wb V, 630.6; GDG VI, 135 f.; LÄ I, 883 f.; Gomaà, Besiedlung II, 137 ff.; Montet, Géographie I, 98

${ }^{14} \mathrm{~Wb} \mathrm{~V}, 630.7$.

${ }^{15}$ Farouk Gomaa, Die Besiedlung Ägyptens während des Mittleren Reiches, 135.

${ }^{16}$ Gardiner, Ancient Egyptian Onomastic, 59.

17 Pierre Montet, Geographie de l'Egypte ancienne, 98.

${ }^{18}$ The two djed pillars depict the Eastern and Western mountains.

${ }^{19}$ Andrew H. Gordon and Calvin W. Schwabe, The quick and the dead, 123.
} 
We have no problem at all with the uniliteral signs, also with the biliteral signs and the triliteral signs in reading, but in this case of that style of writing the name of Djedu

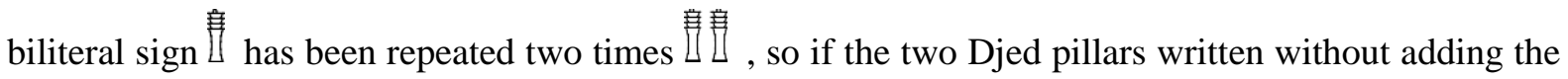
determinative an be read $D d w y$ dual $^{20}$ stability.

For example word $\mathrm{pr}^{\square}$ if it's repeated on writing two times $\square \square$ read a dual prwy, also in the triliteral signs like $n f r{ }^{2}$ if its repeated on writing two times $\stackrel{t}{*} \otimes$ read a dual $n f r w y$.

So in the previous examples can be read with meanings, but in $\triangle \exists=$ the double $D d$ pillars has only one reason and meaning in my opinion that the first $D d$ pillar represents the $D d$ pillar of the God of Busiris and the second $D d$ pillar referring to the name of the city.

The CT Spell 314 mentioned Djedu as $(+d w y)$ 弗 $\Longrightarrow$ A A 5 (Busirian Man), and $(+d w y . t)$ 弗 $\Longrightarrow 410$ 等 (Busirian Woman), in these two cases, the scribe wrote the name of Djedu with Adjectival $\left\{f_{21}\right.$ (once in the masculine and once in the feminine), and in these two cases they were written in CT Spell 314 only,

The CT Spell 337 mentioned Djedu as $\Rightarrow$

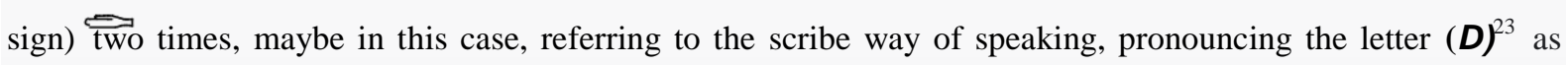
$(\mathbf{d})^{24}$, or the double

CT Spell 622 mentioned Djedu as sign letter (low broad sign) $\leftrightharpoons$ two times, maybe in this case, referring to the skills of the scribe, or the double $\Rightarrow$ gives the same sound of $D d$ 争.

\footnotetext{
${ }^{20}$ A dual form of a noun or a verb in some languages

${ }^{21}$ Egyptologists use the word nisbe (pronounced "Nizz-bee" or "Niss-beh"), taken from Arabic grammar" w", as a term for derived adjectives, see, James P. Allen, Middle Egyptian, 59.

22 Rami van der Molen, A Hieroglyphic Dictionary of Egyptian Coffin, 808.

23 The preceding sound followed by y. if $d$ was like English $d$, then $D$ was like the $d$ in the British pronunciation of dune. To many English speakers, this sounds the same as the $j$ in June. To approximate it, try saying June with the tip of the tongue instead of the flat part, see , James P.Allen, Middle Egyptian, 17.

24 Probably $t$ with some kind of "emphasis" though some Egyptologists think it was more like English d as in sadder, see, James P.Allen, Middle Egyptian, 17.
} 


\section{Index of Djedu pictorial writing in Ancient Egyptian Coffin Texts}

\begin{tabular}{|c|c|}
\hline CT Spell No. & The Iconography of Djedu name \\
\hline Spell 26 & 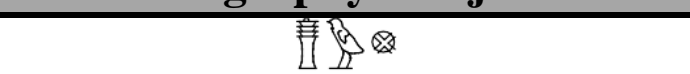 \\
\hline Spell 31 & $\Rightarrow=\hat{R}_{2}$ \\
\hline Spell 32 & $\Rightarrow g$ \\
\hline Spell 34 & $\Rightarrow=8$ \\
\hline Spell 37 & 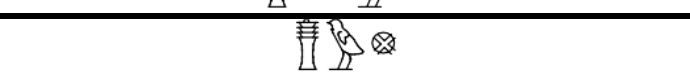 \\
\hline Spell 45 & 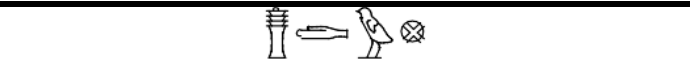 \\
\hline Spell 47 & $\Rightarrow g$ \\
\hline Spell 50 & 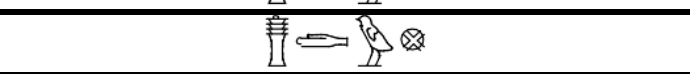 \\
\hline Spell 60 & 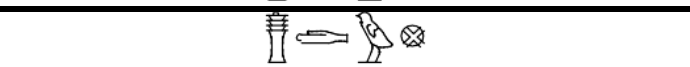 \\
\hline Spell 132 & 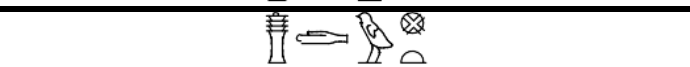 \\
\hline Spell 144 & $\Rightarrow g$ \\
\hline Spell 146 & 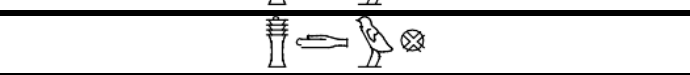 \\
\hline Spell 155 & $\Rightarrow$ \\
\hline Spell 156 & $\exists=\oint_{0}$ \\
\hline Spell 182 & $\Rightarrow \Leftrightarrow$ \\
\hline Spell 197 & 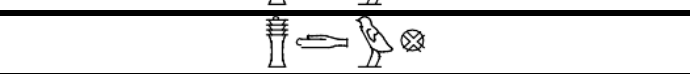 \\
\hline Spell 206 & $\Rightarrow=\oint_{0}$ \\
\hline Spell 215 & $\Rightarrow$ \\
\hline Spell 228 & $\Rightarrow \Leftrightarrow$ \\
\hline Spell 239 & $\Rightarrow \sqrt{n}$ \\
\hline Spell 241 & $\Rightarrow \Rightarrow$ \\
\hline Spell 268 & 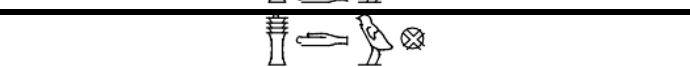 \\
\hline Spell 292 & $\Rightarrow \Leftrightarrow$ \\
\hline Spell 303 & $\Rightarrow \Leftrightarrow$ \\
\hline Spell 312 & 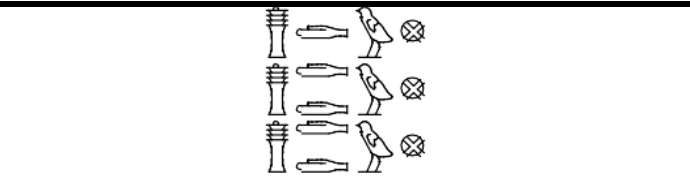 \\
\hline Spell 313 & 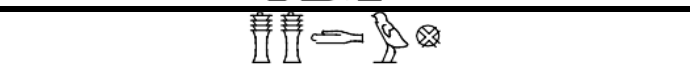 \\
\hline Spell 314 & 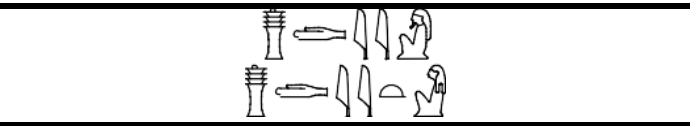 \\
\hline
\end{tabular}


INTERNATIONAL JOURNAL OF

ECO-CULTURAL TOURISM, HOSPITALITY PLANNING

AND DEVELOPMENT

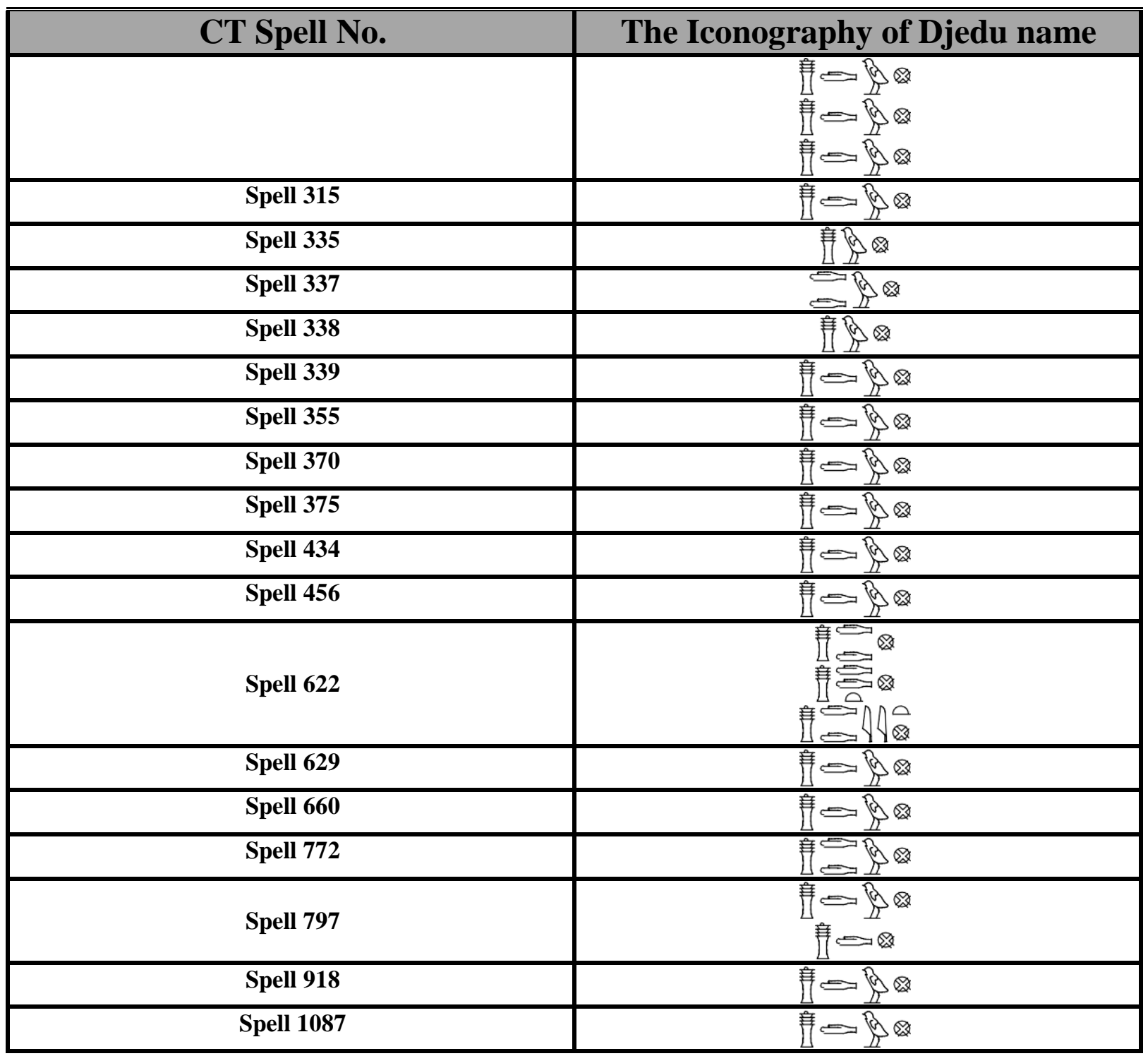

This example very close to previous form in CT Spell 337, but in this case more complete than the other one $\Rightarrow$

The CT Spell 797 mentioned Djedu as

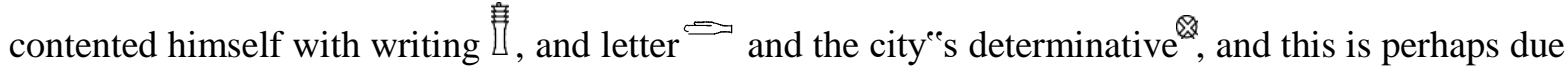
to the small space available to write the written line in which the name of the city was written, and at the same time the letter $\rightleftharpoons$ here is a phonetic complement, which mean that the existence of the letter or not. There is no imperfection in the word or the meaning; just the space is the only controller of the way of writing the name of the city in that mentioned way. 


\section{Conclusion}

The forms for the name of Djedu city in the Coffin Texts has been written for nine different forms, some of it are frequent and common forms in the texts of temples and the ancient Egyptian religious books texts, and some of it appeared only in the Coffin Texts.

The djed pillar is the master of writing the name of Busiris city, of course, with the determinative niwt.

Most of the written evidence in the Coffin Texts confirm that the djed pillar is closely related to the city Djedu, and that this djed pillar / the sacred symbol was later related with the deities that were sanctified in this city of Djedu, starting from the god Andjety until god Osiris, although god Andjety wasn't represented in his human form, Holding this sacred symbol djed pillar.

The most common form show the name of Djedu city in coffin texts is $\Longrightarrow$ it has been repeated 35 times, which is the ideal written form and way of writing the name (Busiris), which begins with the determinative of djed pillar and the phonetic complement $\Rightarrow$ and $h$ and the custom of the city.

Comes in second place $\Rightarrow$ and this written form has been repeated five times, and this form consists of

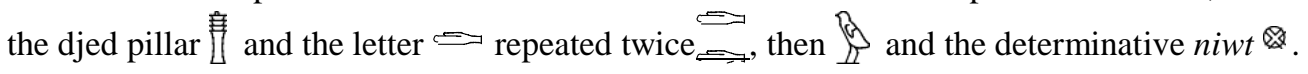

In third place 1 it has been repeated four times.

Fourth place are written forms writing forms have been not repeated in the Coffin Texts, each one of these forms was written once.

The most interesting result due to the analytical study of the forms of Djedu name is $(+d w y)=4$ 争 (Busirian Man), and (+dwy.t) $\Rightarrow 410 \circ$ (Busirian Woman), in these two cases, the scribe wrote the name of Djedu with Adjectival $4{ }^{25}$ (once in the masculine and once in the feminine), and in these two cases they were written in CT Spell 314 only,

The sources used for all the previous spells which mention the name of Djedu which comes from El-Barsha, Aswan, Beni Hasan, Gebelein, Lisht, Meir, Thebes, Siut, Saqqarah, and unknown places.

During the comparisons and analysis between the different forms and style of the name of Djedu writings, I found that the variations of way of writings of word, not about the place of the coffin made in, or for, it just about the Only the available space in the coffin can be controls the scribes, because in each coffin comes from

\footnotetext{
${ }^{25}$ Egyptologists use the word nisbe (pronounced "Nizz-bee" or "Niss-beh"), taken from Arabic grammar" uw", as a term for derived adjectives, see, James P. Allen, Middle Egyptian, 59.
} 
INTERNATIONAL JOURNAL OF

ECO-CULTURAL TOURISM, HOSPITALITY PLANNING

AND DEVELOPMENT

different places belongs to deferent persons, the scribes write the name of Djedu in different styles, so that the scribe Show off his artistic and writing skills.

\section{Bibliography}

Tassie, G. J. 2014 Prehistoric Egypt, London.

2015 "I" $\mathrm{m}$ Osiris, no I"'m Osiris, no I"m Osiris: hairstyles and the afterlife", in: Kousoulis, P. and Lazaridis, L. (eds.) Proceedings of the Tenth International Congress of Egyptologists, University of the Aegean, Rhodes 22-29 May 2008. Leuven/Paris/Dudley, OLA 241, 18731895.

Wilkinson, R. H. 2003 The Complete Gods and Goddesses of Ancient Egypt, London. Allen, J. P.

2005 The Ancient Egyptian Pyramid Texts, Atlanta.

Saleh, M., Sourouzian, H. 1987 Official Catalogue: The Egyptian Museum Cairo, Mainz. Griffiths, J. G.

1980 The Origins of Osiris and his cult, Leiden.

Maspero, G. 1890 tudes gyptiennes II: Un Manuel de Hiérarchie gyptienne et le culte une et les Bestiaux dans les Tableaux des tombeaux de l'ancien empire, Paris: Imprimerie Nationale.

Sethe, K. H. (ed.) 1932 Urkunden des Alten Reichs, Leipzig.

The development of Middle Kingdom Egyptian relief sculptural schools of late Dynasty XI : with an appendix on the trends of early Dynasty XII (2040-1878 B.C.)

Rami van der Molen A Hieroglyphic Dictionary of Egyptian Coffin Texts (Probleme Der Ägyptologie) Hardcover February 9, 2000.

Robert D. Bates 2004 A Dictionary of Middle Egyptian for Students of Biblical Archaeology and Old Testament Studies, Andrews University.

Barta, Winfried Der Königsring als Symbol zyklischer Wiederkehr. Zeitschrift für Ägyptische Sprache undAltertumskunde 98, pp. 5 - 16.

Claude Carrier, Textes Des Sarcophages: du moyen empire egyptien, 3 vols,Paris, 2004.

Faulkner, R. O., A Concise Dictionary of Middle Egyptian, Oxford, 1962. , The Ancient Egyptian Coffin Texts, 3 vols, Warminster, 1973-78.

James P. Allen, Middle Egyptian: An introduction to the language and Culture of Hieroglyphs, Cambridge, UK, 2000.

Leitz, C. (ed.), Lexikon der ägyptischen Götter und Götterbezeichnungen, 8 vols, OLA 110-116 and 129, Leuven, 2002-2003.

Helck, Wolfgang and Otto, Eberhard, Lexikon der Ägyptologie, 7 vols.

Wiesbaden, 1975-1992. 
Donald B. Redford ,Pharaonic King-Lists, Annals and Day-Books: A Contribution to the Study of the Egyptian Sense of History( SSEA Publication ,)Paperback - February 1, 1986

Karl W. Butzer, Early Hydraulic Civilization in Egypt: A Study in Cultural Ecology (Prehistoric Archaeology and Ecology) Paperback, University of Chicago Press; Reprint Edition (August 1, 1976) Hermsen, E., Die Zwei Wege des Jenseits: das altägyptische Zweiwegebuch und seine Topographie, OBO 126, Freiburg and Göttingen, 1991.

Hoffmeier, J. K., „Are There Regionally-Based Theological Differences in the Coffin Texts? $?^{\mathrm{e}}$, in: Willems (ed.), The World of the Coffin Texts, 45-54.

Hornung, E., Altägyptische Höllenvorstellungen, ASAW 59/3, Berlin, 1968.

Richard H. Wilkinson,Reading Egyptian Art: A Hieroglyphic Guide to Ancient Egyptian Painting and Sculpture, Thames and Hudson, 1992.

Robinson, P., ,as for them who know them, they shall find their paths: Speculations on the Ritual Landscapes in the Book of the Two Ways ${ }^{e e}$, in: Mysterious Lands, 139-159. 